\title{
A LONG RUN ARDL INVESTIGATION OF MANUFACTURING ADJUSTMENT TO THE SERVICES ECONOMY IN NIGERIA
}

(iD) Olumuyiwa
Olamade

Department of Economics Caleb University Imota, Nigeria.

Email:olumuyiwa.olamade@calebuniversity.edu.ng

Article History
Received: 22 June 2021
Revised: 26 July 2021
Accepted: 17 August 2021
Published: 9 September 2021
Keywords
Manufacturing
Services economy
Structural transformation
Industrialization
Economic growth
Nigeria
ARDL.
JEL Classification:
L60, L80, E1, Oo,O50,C32

ABSTRACT

The long-run equilibrating relationship between the value-added growth of services and manufacturing is investigated in this research. The study is based on the wellestablished empirical link between manufacturing and service activities, and in particular, manufacturing's servicification. The selected variables' annualized time series were obtained from the World Development Indicators. The paper used the autoregressive distributed lag framework to regress manufacturing value-added growth against service value-added growth while accounting for economic growth, factor input growth, and trade effects. The findings revealed that in Nigeria, a strong performing services sector has a large negative impact on manufacturing performance, whereas capital accumulation and income growth have positive effects. The supply constraint of business services that the manufacturing sector requires is at the root of this finding. The paper advocates for policy frameworks that support the efficient supply of business services as both a manufacturing input and a productivity enhancer for the entire economy.

Contribution/ Originality: The paper's primary contribution is finding that a strong performing traditional services sector may be antithetical to manufacturing modernization and growth. The expected significantly positive effect of services on manufacturing is realized when the economy advances from traditional to modern services facilitating production and cost reduction in other sectors.

\section{INTRODUCTION}

Sustained economic growth is a process of continuous transformation of an economy's structure of production with the pace and magnitude of economic growth conditional on the structure of the growth-leading sector and strength of its linkages to other sectors. In this heterodox economics thinking, the growth-boosting effect of a unit of value-added in agriculture is not necessarily the same as in manufacturing or services. Consequently, sectors differ in their capacity to enhance economic growth. The Kaldorian literature, for instance, ascribed to manufacturing some special characteristics not shared by other sectors of the economy such that a unit of valueadded in manufacturing offer greater opportunities for income growth, capital accumulation, economies of scale, technological innovation, and linkage and spillover effects. However, the concerns about the phenomena of deindustrialization and premature deindustrialization and the rising prominence of services as drivers of growth 
across the world have questioned the role of manufacturing in recent growth episodes and its future capacity to drive growth.

The incidence of the high and increasing share of services in the total GDP and employment globally is well documented in the literature. The debate on the sustainability of service-led growth without a strong manufacturing base is still ongoing and unsettled. What is however not in doubt is that there are strong linkages between the two sectors. Manufacturing produces the machinery, tools and materials needed for building modern infrastructure and equipment that the services sector use to more efficiently run their activities. On the other hand, the manufacturing sector uses some services as essential inputs in their production process as well as perform several services-related activities along the process which manufacturing firms may partly outsource or offshored (ECSIP Consortium, 2014). Given these strong interrelationships, Stehrer et al. (2015) posited that improvements in the performance of the services sectors and the conditions impacting on the interactions of the two sectors should have significant effects on the performance of the manufacturing sector. On this premise, I will interrogate in this paper the implication for manufacturing of the high and growing contribution of the services sector to GDP in Nigeria. The a priori expectation is that if the manufacturing sector in Nigeria receives important inputs to its processes from the services sector and outsource its services-related activities to the services sector, improvement in the services sector's performance should exert a positive and significant influence on manufacturing performance.

The paper is set out as follows. The rest of section 1 discusses the trend relationship of the manufacturing and services sector in Nigeria. Section 2 presents a brief review of the literature. Section 3 lays out the methodological approaches of the study. The results of econometrics analysis will be discussed in Section 4. The work will conclude with recommendations in section 5 .

Table-1. 5-year percentage contribution to GDP and change.

\begin{tabular}{c|c|c|c|c|c}
\hline & \multicolumn{4}{|c|}{ Manufacturing } & \multicolumn{2}{c}{ Services } & \multirow{2}{*}{ Relative contribution } \\
\hline & \% in GDP & Change & \% in GDP & Change & $41 \%$ \\
\hline $1981-1985$ & 20.10 & - & 49.16 & - & $44 \%$ \\
\hline $1986-90$ & 19.39 & -0.71 & 44.23 & -4.93 & $47 \%$ \\
\hline $1991-95$ & 19.29 & -0.10 & 40.80 & -3.43 & $43 \%$ \\
\hline $1996-2000$ & 17.19 & -2.10 & 40.29 & -0.51 & $28 \%$ \\
\hline $2001-05$ & 11.74 & -5.44 & 42.48 & 2.18 & $16 \%$ \\
\hline $2006-10$ & 7.96 & -3.78 & 49.84 & 7.36 & $16 \%$ \\
\hline
\end{tabular}

\subsection{Manufacturing - Services Trend Relationships in Nigeria}

Table 1 presents the half-decadal average contributions to the GDP of both sectors. In relative terms, services contributed to the GDP more than twice manufacturing's in the first two decades and thereafter dramatically increased its contribution to more than five times. The phenomena increase in services share of the GDP at the expense of manufacturing indicates a shift of resources from agriculture manufacturing to services which may further exacerbate manufacturing's declining share in the GDP, if not arrested. Manufacturing's contribution to the GDP declined all through the periods falling from $20.10 \%$ in $1981-1985$ to $9.65 \%$ in $2016-1091$, services on the other hand recovered from its declining contribution to the GDP from 2001 and maintained increasing addition to the GDP thereafter. Though, both sectors witnessed diminishing contribution to the GDP over the two decades from 1981-2000, the rate of decline was more pronounced in services than manufacturing. Whereas, the rate of decline in services' contribution to the GDP averaged $-8.87 \%$, manufacturing in the same period witnessed a modest decline rate of $-2.91 \%$. Figure 1 which plotted the percentage change in the contribution of both sectors to the GDP against time helps us to distil important characteristics of the change in each sector's contribution to the GDP. The following facts are made evident by the graph:

i. Manufacturing recorded a prolonged period of negative change in contribution to the GDP than services. 
ii. Recovery from a negative change in contribution to the GDP is stronger in services than in manufacturing.

iii. A negative rate of change in services GDP share almost always is accompanied by a negative rate of change in manufacturing. However, a positive rate of change in services share of the GDP is not necessarily accompanied by a positive rate of change in manufacturing GDP share.

iv. For the most part, changes in the contribution to GDP of the two sectors move in the same direction.

v. In the last decade of the analysis, services rate of contribution to GDP is declining but positive. Change in manufacturing's share of GDP turned positive and increasing but lower in magnitude relative to services.

Both sectors operating under the same economic climate has largely responded differently to the economy's macroeconomic stimulus. The macroeconomic environment appears to have been more services friendly particularly from 2001 when the services sector more strongly asserted its position as the driver of GDP growth relative to the previous decades. The concern following from the observed trends of both sectors is what the trends portend for manufacturing performance or how the manufacturing sector adjust to services dominance of the GDP, ceteris paribus. Section 4 of the paper which analyzes the econometric results of the specified model will address this concern.

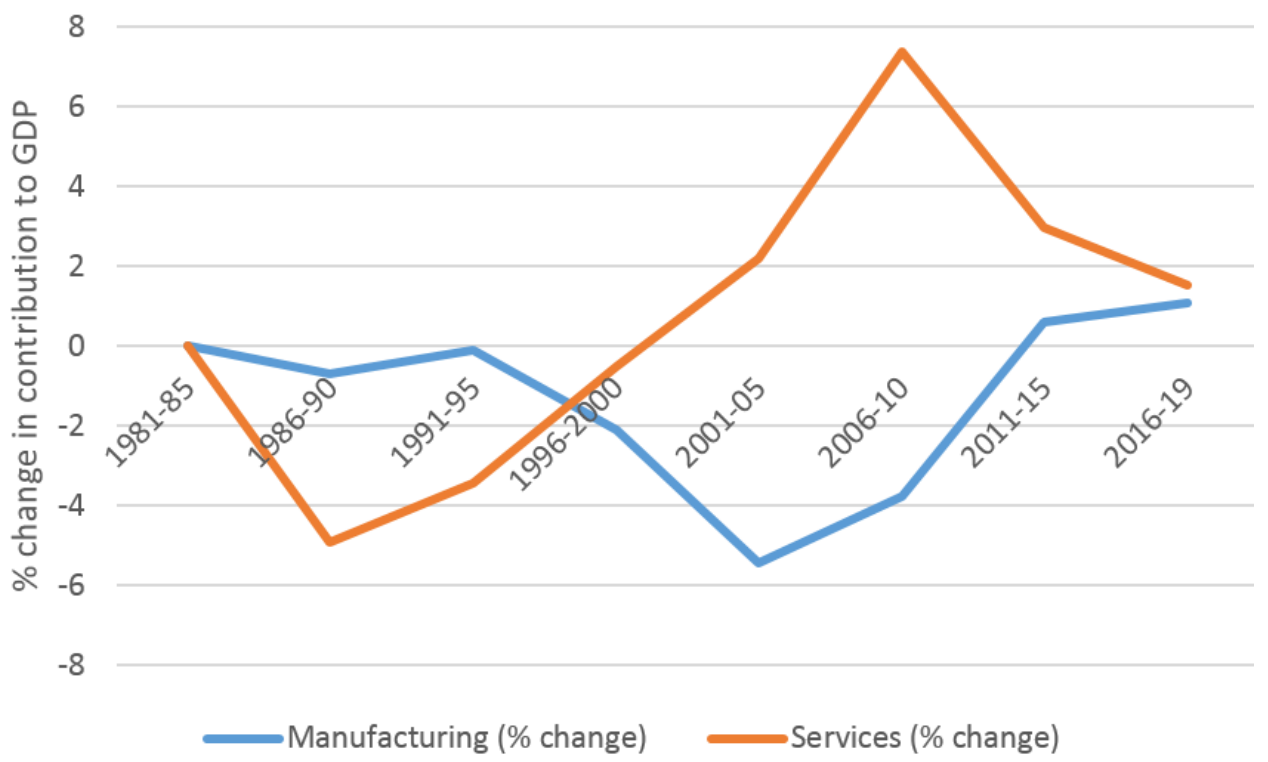

Figure-1. Percentage change in contribution to GDP of manufacturing and services.

\section{REVIEW OF LITERATURE}

Economists and policymakers, based on the growth trajectories of countries, have come to agree that the continuous transformation or diversification of the structure of domestic production is a basic requirement for achieving higher levels of sustainable development (Bhatta, 2014) and an indispensable characteristic of modern economic development (Kuznets, 1971). Successful structural transformation and the accompanying sustainable development by any country is associated with three principal capacities: the capacity to generate new economic activities, strengthen economic linkages within the economy, and create domestic technological capabilities (Ocampo, 2007). This dimension to sustainable economic growth rather than focus on the identification of the determinants of growth, which is the preoccupation of mainstream growth theories, relied on sectorial growth and their interdependencies.

The idea that sectors may differ in their capacity to boost economic growth and thus the need to manage economic linkages across the economy first appeared in the dual economy model of Lewis (1954) and Fei and Ranis (1964). Baumol (1967) modelled structural change based on technological change according to which uneven 
growth is an inherent feature of the economic growth process as different sectors grow at different rates owing to different rates of technological progress. The dual economy model predicts agriculture as the growth-leading sector which provides the capital basis for the industrialization stage of economic development. Hwa (1989) attributed earlier growth in the industrial sector to faster growth of the agricultural sector, ceteris paribus. In the industrial stage of development, manufacturing is regarded as a strategic sector endowed with "special characteristics" that enables it to stimulate productivity and innovation throughout the economy. These somewhat exclusive "special characteristics" thus made manufacturing the engine of growth of the industrial stage. Traditionally, arguments in favor of the importance of manufacturing as a growth engine have revolved around its influence on income, structural change, technology generation and diffusion and economies of scale. This argument can be succinctly summarized under the following points (see Szirmai (2009)):

- The degree of industrialization empirically correlates with per capita income in developing countries, such that the least industrialized are the poorest countries and the more successful countries are the better industrialized.

- Transfer of resources from agriculture to manufacturing at the first stage of structural transformation provides a structural change bonus because productivity is higher in the manufacturing sector than in the agricultural sector. According to Timmer and Szirmai (2000), the bonus hypothesis postulates a positive relationship between structural change and economic growth. The postulation rest on the assumption that in the process of development, economies migrate from sectors with comparatively low value-added per labor unit to those with a higher one (Deleidi, Meloni, \& Stirati, 2020).

- A transfer of productive resources to manufacturing contributes more to economic growth as manufacturing is assumed to be more dynamic than other sectors.

- Transfer of resources from manufacturing to services is subject to Baumol's disease. However, as the services sector becomes very dynamic the argument may be reversed.

- Manufacturing being spatially concentrated offers special opportunities for capital accumulation than the spatially dispersed agriculture.

- Manufacturing offers special opportunities for economies of scale, which are less available in agriculture or services. The emergence of new ICT technologies has however conferred scale economies advantage on ICT based service as the marginal costs of additional units of service approach zero. Hence, scale advantages are no longer limited to manufacturing. Also, in more recent years, ICT has triggered an industrial revolution and has been a major source of productivity growth (Hsieh \& Rossi-Hansberg, 2019).

- Manufacturing offers special opportunities for both embodied and disembodied technological change. Technological change and innovations are essential sources of structural change which is the very centre of modern economic growth. Based on the observation that technological change took place mainly in the manufacturing sector and diffuses from there to other economic sectors such as the service sector, the expansion of manufacturing is a driving force for economic growth (Cornwall, 1977; Kaldor, 1970; Syrquin, 1986; Verspagen, 2000).

- Linkage and spillover effects are stronger for manufacturing than for agriculture or mining. Linkage and spillover effects are presumed to be stronger within manufacturing than within other sectors. Linkage and spillover effects between manufacturing and other sectors such as services or agriculture are also very powerful.

- As per capita incomes rise, the share of agricultural expenditure in total expenditure declines and the share of expenditure on manufactured goods increases (Engel's law).

In a 2014 publication, Felipe, Mehta, and Rhee found that the engine of growth hypothesis was responsible for the rapid and sustained economic growth and catch-up of the 1970s. Cantore, Clara, Lavopa, and Soare (2017) for a sample of 80 countries find empirical support for the engine of growth hypothesis provided that manufacturing 
value-added growth promotes structural transformation. Under the condition of the presence of a sufficient level of human capital, Szirmai and Verspagen (2015) in a panel of 92 countries for 1950-1970, 1970-1990 and 1990-2005 reported that manufacturing acts as an engine of growth for low and some middle-income countries. Both Felipe, Mehta, and Rhee (2014) and Haraguchi, Cheng, and Smeets (2017) empirically argued that manufacturing in developing countries remains a growth engine despite declining manufacturing value-added and manufacturing employment shares. In their submissions, premature deindustrialization or non-industrialization in developing countries is rather the symptoms of manufacturing development failures and not of a change in the development potential of manufacturing activities. Distinguishing between the growth effect of manufacturing value-added share and employment share, Felipe et al. (2014) opined that high and sustained economic growth is supported more by manufacturing employment so that the path to sustained prosperity via industrialization runs through the way of increasing manufacturing employment. The key to unlocking the special characteristics of manufacturing thus is found in the capacity of developing countries to continually increase manufacturing employment.

The expansion of the service sector is traditionally interpreted as a by-product of growth-driven rising incomes occasioned by technical progress in manufacturing. Hence, growth is often characterized as service-biased and not service-led (Fan, Peters, \& Zilibotti, 2021). A large number of empirical literature now support the service-led growth hypothesis (see (Ghani, 2011; Nayyar \& Cruz, 2019; Shepherd, 2019)) and establishes the special characteristics of services that are somewhat similar to manufacturing. Despite the special characteristics of manufacturing and the empirically proven strong growth potential, the services sector have emerged as the most dynamic sector of world trade (WTO, 2019) a major driver of growth in the GDP, trade and employment in all income groups, and a source of structural change. Rising services output and employment have been observed to foster two different kinds of structural change - in the developed economies structural transformation has taken the form of a shift of resources from industry to services whereas, in the developing economies productive resources have principally moved from agriculture to services (UNCTAD, 2017). Services structural transformative power, according to Balchin (2017) may be attributed to these four dynamic characteristics:

Tradability: The narrow idea of non-tradability of services only relates to final consumption services where physical proximity is required for production and consumption, or where the services are associated with delivery in a fixed location. Today, all service inputs are tradable when embodied in intrinsically tradable products Low (2017). Te Velde (2017) reported that for many low-income countries trade in services has grown faster than the trade in goods since 1991. Similarly, the share of services value added in goods exports from these countries is expanding at a fast rate.

Employment creation: The growth of the services sector's output has led to a concomitant shift in employment structure across all income groups. D'Agostino and Ward-Warmedinger (2006) in their study on some European countries and the United States reported the escalating creation of jobs in the services sector. They noted that in 2001 services employment share in all the countries considered was more than double that recorded in industry and agriculture. Similarly, In OECD member countries more than 70 per cent of the employed labor force worked in the services sector (OECD, 2005). In 2017, this proportion exceeded 80 per cent among high-income industrialized OECD countries, except for Greece (Buckley \& Majumdar, 2018). The National Skills Commission (2020) of Australia in a 5-year projection up to November 2025 forecasted that over three-fifths (64.4\%) of total employment growth in the country will come from just four sub-sectors of the services. In Africa, the services sector's share in total employment is growing increasing from 34.1 per cent in 2011 to 36.1 in 2019 and is projected to reach 36.2 per cent by 2020 and 36.4 per cent by 2021 with northern and southern Africa leading the pack (ILO, 2020). It follows that a high-performing services sector is an essential requirement to strengthen economic growth and improve the foundations for the future performance of economies. At the core of the process is the capacity of countries to effectively transfer labour from other sectors into the services. 
Inputs into manufacturing: The global value chain framework presented manufacturing and services activities as a web of networks since any good/service is produced by both activities. The manufacturing value chain begins with services (R\&D and design) and ends with services (distribution, marketing, and other services) with the core manufacturing occurring in the middle of the value chain. For the core manufacturing activities, logistics services and other services such as maintenance and repair of the production infrastructure or financial services are needed so that the manufacturing and service production stages are almost indistinguishable. Similarly, the services value chain is a bundle of goods and services comprising physical networks (transport, telecoms, electricity, etc.) which are typically dedicated to providing solutions for manufacturing firms, and virtual networks (banking, insurance, social media, etc.) which are responsible for all consulting, business supporting, and personal services (see (ECSIP Consortium, 2014; Miroudot, 2019)).

Enhancement of productivity change, growth and competitiveness in other sectors: This relates to the second wave of the increasing share of services in the economy which occur at higher levels of income. The share of services increases as the economy upgrade from traditional services to modern services in communication, finance, computer and business services (Eichengreen \& Gupta, 2011). At this stage, the whole economy is served by the benefits of scale economies in services thus facilitating and production and trade in other sectors and bringing down their costs. This is particularly important for Africa where low services access and high costs stifle the development of value chains and economic transformation (Balchin et al., 2016). In a 2017 publication, Diao, McMillan, and Rodrik (2017) argue that the services sector has contributed to labour productivity growth in developing economies through structural change and productivity improvements within the services sector in Africa and Latin America respectively and through both channels in East Asia.

Availability and access to high-productivity services is a defining feature of modern competitive advantage and a key to ascending the global value chain. The capacity to leverage advanced services will be critical for Successful industrialization/reindustrialization and sustainable development.

\section{DATA, MODEL AND METHODS}

As previous studies have shown, growth in manufacturing $(\Delta \mathrm{mn})$ is determined by many factors including capital stock, labour force, economic growth, exports, trade openness, and structural change. The thrust of the study is to examine the effect of services sector growth on manufacturing growth while controlling for the growth effects of trade, factor inputs, and economic growth. The seven variables for analysis are manufacturing valueadded $(m n)$, services value-added $(s e)$, income pa capital $(y c)$, exports of goods and services (ex), and gross fixed capital formation as a proxy for the input of capital $(k p)$. These five are measured in 2010 constant United States dollars. Others are the working-age population (15-64 years) as a proxy for the input of labour $(l b)$, and the ratio of trade to GDP as a proxy for trade openness $(t d)$. Growth for each variable is measured as the difference in value between two-time points (e.g. $\left.\Delta m n=m n(t)-m n(t-1)=m_{t}\right)$. The difference of each variable is thereafter expressed in its natural logarithm except for trade. Annual time series data for Nigeria spanning 1981 to 2019 was extracted from the World Development Indicators (WDI), a World Bank database. The long-run empirical model to capture the effects of growth in these variables on manufacturing growth is specified as follows:

$\log (\mathrm{mn})_{\mathrm{t}}=\alpha_{0}+\alpha_{1} \log (\mathrm{se})_{\mathrm{t}}+\alpha_{2} \log (\mathrm{kp})_{\mathrm{t}}+\alpha_{3} \log (\mathrm{lb})_{\mathrm{t}}+\alpha_{4} \log (\mathrm{ex})_{\mathrm{t}}+\alpha_{5} \log (\mathrm{yc})_{\mathrm{t}}+\alpha_{6}(\mathrm{td})_{\mathrm{t}}+\mu_{\mathrm{t}}$

where log represents the natural logarithm of the growth of the variables and $\mu_{\mathrm{t}}$ the error terms.

\subsection{Unit Root Tests}

Before estimating the specified model to determine the long-run relationship of the variables used as regressors, I first check whether the series are integrated of order $\mathrm{O}$ or they follow a non-stationary trend and are of order 1. For this purpose, 1 use both the augmented Dickey-Fuller (ADF) and DF-GLS tests. The DF-GLS test of Elliott, Rothenberg, and Stock (1996) modifying the Dickey-Fuller test statistic using a generalized least squares 
(GLS) rationale provides a more efficient version of the ADF t-statistic and thus a fitting complement to the ADF test. Both tests the null hypothesis of unit root against the alternative that the null is not true. Given that the variables are stationary at not more than one difference $[I(d)<2]$, the existence of a long-run relationship among the variables will be determined with the ARDL bounds test.

\subsection{ARDL Bounds Test}

The ARDL F-bounds technique (Pesaran \& Shin, 1999; Pesaran, Shin, \& Smith, 2001) tests the null hypothesis that there is no cointegration among variables against the alternative that the null is not true. Importantly, it demands that the variables are integrated at order 0,1 or mixed. In identifying whether a cointegration relationship exists between the variables, the upper bound of the F-bounds test assumes that all the regressors are integrated at order 1 and the lower bound assumes that the regressors are integrated at order 0 . The null hypothesis is rejected if the calculated F-statistic is greater than the upper bound and the existence of cointegration is accepted as proven. Haug (2002) has argued that the ARDL approach to cointegration provides a better result for small sample data set such as in this study compared to traditional approaches to cointegration like Engle and Granger (1987); Johansen and Juselius (1990) and Phillips and Hansen (1990). With the ARDL bounds testing, the unrestricted ECM model seems to take satisfactory lags that captures the data generating process in a general-to-specific framework of specification (Laurenceson \& Chai, 2003).

Granted that the variables are cointegrated, we proceed to estimate both the long-run equilibrating relationship and the dynamic short-run effects within the ARDL framework. The error correction term (ECT) will be reported alongside the bounds test to firmly establish the existence of a long-run relationship of the variables. The ECT parameter is expected to be negative and significant to conclude the cointegration of the variables. In addition to confirming variables cointegration, the ECT specified the speed of adjustment to long-run equilibrium from short-run deviations.

\subsection{Regression Diagnostics}

Diagnostics are very crucial to determine the degree of reliance that can be placed on the regression results for inference and policy recommendations. Tests of the behaviour of the disturbance terms for normality (Jarque-Bera test), serial correlation (Breusch-Godfrey Serial Correlation LM Test) and heteroskedasticity (Breusch-PaganGodfrey test) will be carried out. The probability value of the test statistic in each case is expected to be greater than 0.05. The constancy of the long-run parameters will be tested by applying CUSUM and CUSUM of Squares tests proposed by Brown, Durbin, and Evans (1975) to the model's residuals. The test finds parameter stability if both the CUSUM and CUSUM of Squares stay within the area between the two critical lines.

Table-2. Result of unit root tests.

\begin{tabular}{|c|c|c|c|c|c|c|}
\hline \multirow[t]{2}{*}{ Variable } & \multicolumn{2}{|c|}{ Levels } & \multicolumn{2}{|c|}{$1^{\text {st }}$ diff. } & \multirow[t]{2}{*}{ Max lag } & \multirow[t]{2}{*}{$I(n)$} \\
\hline & ADF & DF-GLS & ADF & DF-GLS & & \\
\hline Log_mn_ & $-4.550499 * * *$ & $-3.745829 * * *$ & - & - & 0 & $I(0)$ \\
\hline Log_se_ & -1.940944 & -1.868448 & $-9.903835^{* * * *}$ & $-8.363622^{* * *}$ & 2 & $I(1)$ \\
\hline Log_kp_ & $-4.066185^{* * * *}$ & -1.962318 & - & $-11.02975^{*} * *$ & 3 & $I(0,1)$ \\
\hline Log_lb_ & $-2.837077^{*}$ & -1.431624 & - & $-6.765886^{* * * *}$ & 1 & $I(0,1)$ \\
\hline Log_ex_ & $-8.958948 * * *$ & $-8.189225^{* * *} *$ & - & - & 1 & $I(0)$ \\
\hline Log_yc_ & $-3.874490^{* * * *}$ & $-1.995819^{* *}$ & - & - & 1 & $I(0)$ \\
\hline td & $-2.738191^{*}$ & -2.460030 & - & $-6.163017^{*} * *$ & 1 & $I(0,1)$ \\
\hline
\end{tabular}

\section{RESULTS AND DISCUSSION}

The evidence provided in Table 2 by the ADF test is that all the variables are levels stationary and are thus integrated of order 0 , except for the $(s e)$ series that both tests indicated to have a stochastic trend. On other hand, 
the DF-GLS test indicates that the null hypothesis cannot be rejected for the time series of $(k p),(l b)$ and $(t d)$. After taking the first differences of the three variables, the tests reject the null hypothesis of unit root at less than 0.01 level of significance. Given that the series exhibits a mixed integrating order, the variables fit the requirement for the bounds cointegration technique. Accordingly, we apply the ARDL cointegration technique and subsequently estimate the ARDL model for the long-run coefficients and short-run dynamic effects. The cointegration test is reported in Table 3.

Table-3. Result of bounds cointegration test.

\begin{tabular}{c|c|c|c|c}
\hline Test Statistic & Value & Signif. & $\mathbf{I}(\mathbf{0})$ & $\mathbf{I}(\mathbf{1})$ \\
\hline F-statistic & 7.368370 & $10 \%$ & 1.99 & 2.94 \\
\hline $\mathrm{k}$ & 6 & $5 \%$ & 2.27 & 3.28 \\
\hline & & $1 \%$ & 2.88 & 3.99 \\
\hline CointEq(-1) & -1.01433 & 0.11371 & -8.92067 & 0.0000 \\
\hline
\end{tabular}

As seen in Table 3 the value of the calculated F-statistic, 7.37, is greater than the upper bound of 3.99 at the 0.01 level of significance, the null hypothesis is rejected. According to Banerjee, Dolado, and Mestre (1998) a highly significant ECT provide additional evidence of the existence of a stable long-term relationship. The results thus indicate that there is a convergence in the long-run dynamics of $\log (\mathrm{se}), \log (\mathrm{kp}), \log (\mathrm{lb}), \log (\mathrm{ex}), \log (\mathrm{yc})$, and $(\mathrm{td})_{\mathrm{t}} \mathrm{when}$ $\log (\mathrm{mn})_{\mathrm{t}}$ is the dependent variable. We can now meaningfully, considering the presence of cointegration, estimate a long-run levels model and a restricted ECM that make possible the measurement of long-run equilibrating relationships and short-run dynamic effects.

Table-4. Long-run equilibrating relationships.

\begin{tabular}{l|c|c|c|c}
\hline Variable & Coefficient & Std. Error & t-Statistic & Prob. \\
\hline LOG_KP_ & 1.044126 & 0.361268 & 2.890171 & 0.0091 \\
\hline LOG_LB_ & -50.0971 & 15.2701 & -3.28073 & 0.0037 \\
\hline LOG_SE_ & -1.45462 & 0.588691 & -2.47094 & 0.0226 \\
\hline LOG_YC_- & 1.192485 & 0.649958 & 1.834709 & 0.0815 \\
\hline LOG_EX_ & -0.11592 & 0.25446 & -0.45554 & 0.6536 \\
\hline TD & -0.008 & 0.005387 & -1.48488 & 0.1532 \\
\hline C & 1.460008 & 0.417668 & 3.495621 & 0.0023 \\
\hline
\end{tabular}

\subsection{Long-Run and Short-Run Dynamic Effects}

Capital accumulation presents the most significant positive influence on manufacturing growth in both the long run (see Table 4) and the short run (see Table 5). The magnitude, as well as the significance of capital accumulation's positive impact on manufacturing performance, increased over time in the short run. With an extra dollar increase in capital accumulation yielding more than a proportionate increase in manufacturing value-added, in the long run, capital deepening is a sin qua non for manufacturing and economic growth in Nigeria. This result registers with Chen (1992) who found that a country with a larger initial capital-labour ratio will continue to have the higher ratio and hence will maintain higher per capita income. Growth in per capita income is found also to be significant for manufacturing performance in both the short and the long run. This result is in harmony with several others that have demonstrated an empirical correlation between the degree of industrialization and the levels of per capita income in developing countries (Szirmai, 2011). Comparing the two significant positive effects, in the long run, Per capita income growth exerts a greater growth effect on manufacturing than capital accumulation making it the principal determinant of manufacturing performance in Nigeria. The effect of international trade on the manufacturing sector measured as exports of goods and services and the degree of trade openness is negative but insignificant both in the long - and short run. Findings on trade and manufacturing 
performance in Nigeria has been mixed, however, this study agrees with Adekunle and Akinwale (2020); Emerenini and Ohadinma (2018) that measures of trade inhibit the development of the manufacturing sector.

A strong performing services sector is found to significantly undermine the growth of the manufacturing sector. Contrary to the expectation that as manufacturing increasingly becomes services intensive, a growing services sector will propel growth in manufacturing output, the growth in services value-added over the study period had a significantly negative effect on manufacturing value-added expansion. The reported relationship raises some questions about the two sectors and their nexus such as; how service-intensive is the manufacturing sector?, how do Nigeria's manufacturing firms access services - internally produced or sourced?, are modern services required in manufacturing available and accessible in Nigeria? Evidence-based answers to these questions will help to properly situate the causes of growing services and shrinking manufacturing sectors in Nigeria. Available evidence however indicates that the provision of business services such as electricity, telecommunication and transportation are major constraints to manufacturing growth in Nigeria (Chete, Adeoti, Adeyinka, \& Ogundele, 2014). In a study of services sector growth in Nigeria, Olamade (2017) reported that major producer services like communication, real estate and business services, and utilities are not significant in explaining the performance of the manufacturing sector. In Lodefalk (2014), it is posited that where the activities that generate a higher share of the total value of a product weigh towards services, manufacturing firms tend to domesticate such services as a strategy to enhance productivity. Literature evidence thus suggests that the observed significant negative adjustment of manufacturing to services growth found in this study is to be expected.

Table-5. Short run dynamic effects

\begin{tabular}{|c|c|c|c|c|}
\hline \multicolumn{5}{|c|}{ Dependent Variable: LOG_MN__ $_{-}$} \\
\hline \multicolumn{4}{|c|}{ Selected Model: $\operatorname{ARDL}(1,2,1,1,0,3,0)$} & \multirow[b]{2}{*}{ Prob.* } \\
\hline Variable & Coefficient & Std. Error & t-Statistic & \\
\hline 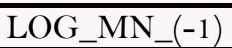 & -0.01433 & 0.164256 & -0.08726 & 0.9313 \\
\hline $\mathrm{LOG}_{-} \mathrm{KP}$ & 0.325103 & 0.208003 & 1.562976 & 0.1337 \\
\hline LOG_KP_- $\left.\_-1\right)$ & 0.241788 & 0.132909 & 1.819209 & 0.0839 \\
\hline LOG_KP_(-2) & 0.492199 & 0.16581 & 2.968447 & 0.0076 \\
\hline LOG_LB_ & -30.9885 & 12.85579 & -2.41047 & 0.0257 \\
\hline LOG_LB_(-1) & -19.8266 & 12.44636 & -1.59296 & 0.1269 \\
\hline LOG_SE_- & -0.73275 & 0.54892 & -1.3349 & 0.1969 \\
\hline LOG_SE_(-1) & -0.74272 & 0.410809 & -1.80794 & 0.0857 \\
\hline $\mathrm{LOG}_{-} \mathrm{YC}_{-}$ & 1.209576 & 0.592582 & 2.041195 & 0.0546 \\
\hline LOG_EX_ & -0.17955 & 0.088842 & -2.02104 & 0.0569 \\
\hline LOG_EX_(-1) & -0.11779 & 0.091007 & -1.29431 & 0.2103 \\
\hline LOG_EX_(-2) & 0.023443 & 0.099113 & 0.236529 & 0.8154 \\
\hline LOG_EX_(-3) & 0.156323 & 0.080206 & 1.949015 & 0.0655 \\
\hline TD & -0.00811 & 0.005245 & -1.54679 & 0.1376 \\
\hline $\mathrm{C}$ & 1.480933 & 0.495949 & 2.986061 & 0.0073 \\
\hline R-squared & 0.695549 & \multicolumn{2}{|c|}{ Mean dependent var } & 0.01939 \\
\hline
\end{tabular}

Table-6. Result of diagnostics.

\begin{tabular}{l|c|c|c}
\hline \multicolumn{2}{l|}{ Breusch-Godfrey Serial Correlation LM Test: } & \\
\hline F-statistic & 0.281282 & Prob. F $(2,18)$ & 0.7581 \\
\hline Obs*R-squared & 1.060724 & Prob. Chi-Square $(2)$ & 0.5884 \\
\hline Heteroskedasticity Test: Breusch-Pagan-Godfrey & \\
\hline F-statistic & 0.889437 & Prob. F(14,20) & 0.5809 \\
\hline Obs*R-squared & 13.42976 & Prob. Chi-Square $(14)$ & 0.493 \\
\hline Histogram-Normality Test: & 0.523095 & & \\
\hline Jarque-Bera & & \\
\hline
\end{tabular}




\subsection{Diagnostics of the Residuals}

Results of diagnostic tests in Table 6 suggest that the estimations of long-run coefficients and ECM are free from serial correlation, heteroskedasticity and non-normality at a 0.05 level of significance. Inspection of both the CUSUM and CUSUM of Squares figures indicates that the estimated model pass the parameter stability test, thus the parameters are stable over the study period at a 0.05 level of significance. The value of adjusted $\mathrm{R}^{2}$ of the model being close to 70 per cent is relatively high exemplifying a good fit of the model.
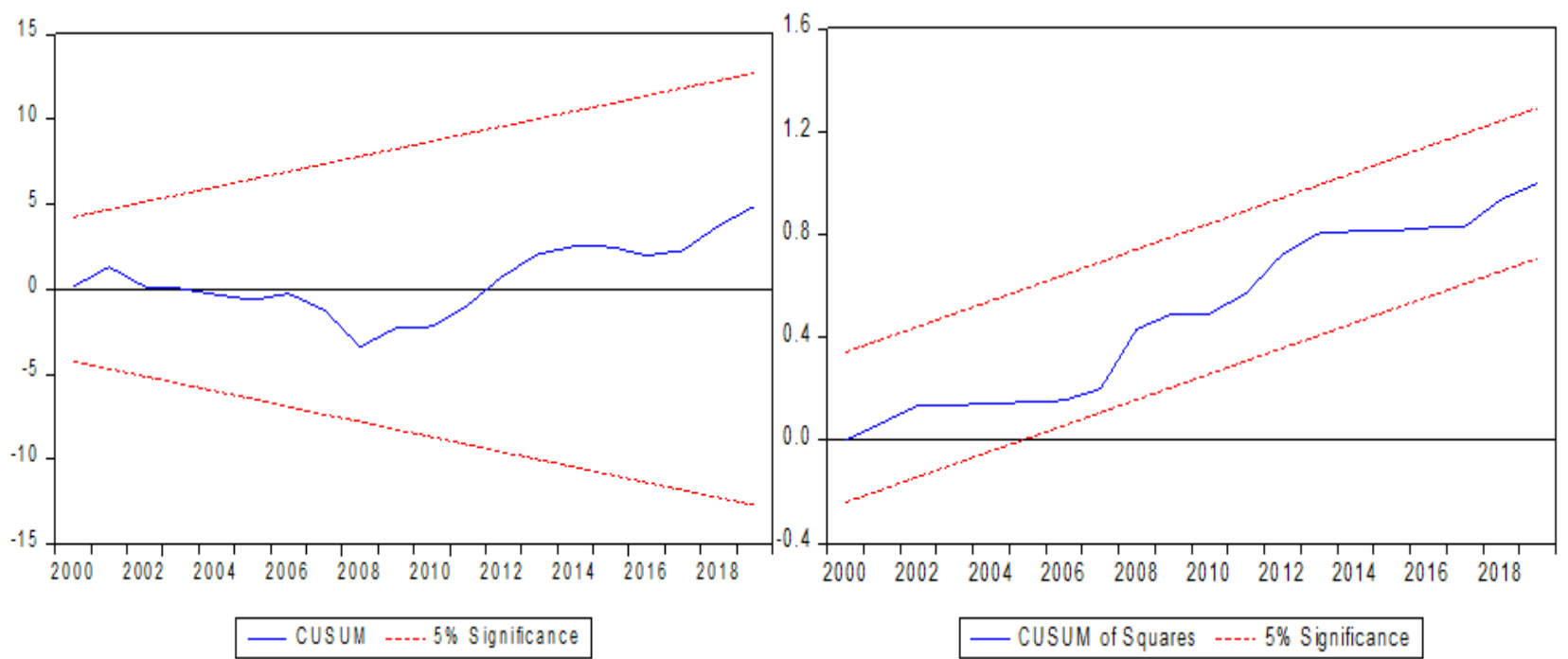

Figure-2. Stability of long-run parameters test.

\section{CONCLUSION}

This paper investigates the long-run equilibrating relationship between the values added of services and manufacturing, premised on the well-established empirical relationship between manufacturing and services activities and in particular the servicification of manufacturing. The results showed that a strong performing services sector in Nigeria exerts a significant negative influence on manufacturing performance. Underlying this result is the low and inefficient supply of business services required by the manufacturing sector which necessitated, in most cases the in-house supply of the required services by the manufacturing firms. Utilities like electricity and water are predominantly provided by manufacturing firms. The services sector though the largest sector of the economy and the major growth factor is predominantly powered by personal services, thus the services sector in Nigeria is not a significant supplier of inputs to the manufacturing sector. As the main driver of services growth (personal services) competes directly with manufacturing for the consumers' income, services growth may exert a negative influence on manufacturing expansion. Services and manufacturing are better linked and mutually reinforcing with an efficient and adequate supply of business services. This paper advocate for policy frameworks that support the efficient supply of business services as both a manufacturing input and a productivity enhancer for the entire economy.

Funding: This study received no specific financial support.

Competing Interests: The author declares that there are no conflicts of interests regarding the publication of this paper.

\section{REFERENCES}

Adekunle, O. E., \& Akinwale, S. O. (2020). Trade liberalization and manufacturing Sector in Nigeria. Academic Journal of Economic Studies, 6(3), 90-96.

Balchin, N., Hoekman, B., Martin, H., Mendez-Parra, M., Papadavid, P., Primack, D., \& Te Velde, D. W. (2016). Trade in services and economic transformation. A Report for the DFID-BIS Trade Policy Unit, UK (November 2016). 
Balchin, N. (2017). Why services are important for industrialisation and economic transformation. In B, Hoekman \& D. W. te Velde (Eds). Trade in services and economic transformation: A new development policy priority (pp. 8-10): Overseas Development Institute.

Banerjee, A., Dolado, J., \& Mestre, R. (1998). Error-correction mechanism tests for cointegration in a single-equation framework. Journal of Time Series Analysis, 19(3), 267-283. Available at: https://doi.org/10.1111/1467-9892.00091.

Baumol, W. J. (1967). Macroeconomics of unbalanced growth: The anatomy of urban crisis. The American Economic Review, 57(3), 415-426.

Bhatta, G. R. (2014). Structural changes in a small and open economy: Evidences from Nepal. NRB Working Paper(23), 1-20.

Brown, R. L., Durbin, J., \& Evans, J. M. (1975). Techniques for testing the constancy of regression relationships over time. Journal of the Royal Statistical Society: Series B (Methodological), 37(2), 149-163. Available at: https://doi.org/10.1111/j.2517-6161.1975.tb01532.x.

Buckley, P., \& Majumdar, R. (2018). The services powerhouse: Increasingly vital to world economic growth. Deloitte Insights, 12.

Cantore, N., Clara, M., Lavopa, A., \& Soare, C. (2017). Manufacturing as an engine of growth: Which is the best fuel? Structural Change and Economic Dynamics, 42, 56-66. Available at: https://doi.org/10.1016/j.strueco.2017.04.

Chen, Z. (1992). Long-run equilibria in a dynamic Heckscher-Ohlin model. Canadian Journal of Economics, 25(4), 923-943. Available at: https://doi.org/10.2307/135772.

Chete, L. N., Adeoti, J. O., Adeyinka, F. M., \& Ogundele, O. (2014). Industrial development and growth in Nigeria: Lessons and challenges (pp. 1-40). WIDER Working Paper No. 8.

Cornwall, J. (1977). Modern capitalism: Its growth and transformation. Oxford: Martin Robertson.

D’Agostino, R. S., \& Ward-Warmedinger, M. (2006). Sectoral explanations of employment in Europe the role of services. Working Paper Series No 625, European Central Bank.

Deleidi, M., Meloni, W. P., \& Stirati, A. (2020). Tertiarization, productivity and aggregate demand: Evidence-based policies for European countries. Journal of Evolutionary Economics, 30(5), 1429-1465. Available at: https://doi.org/10.1007/s00191019-00647-6.

Diao, X., McMillan, M., \& Rodrik, D. (2017). The recent growth boom in developing economies: A structural-change perspective. Working Paper No. 23132.

ECSIP Consortium. (2014). Study on the relation between industry and services in terms of productivity and value creation (pp. 1-118). Final Report, Vienna, October 30.

Eichengreen, B., \& Gupta, P. (2011). The service sector as India's road to economic growth. India Policy Forum, National Council of Applied Economic Research, 7(1), 1-42.

Elliott, G., Rothenberg, T. J., \& Stock, J. H. (1996). Efficient tests for an autoregressive unit root. Econometrica, 64(4), 813-836.

Emerenini, F. M., \& Ohadinma, C. M. (2018). Impact of trade liberalization on manufacturing output in Nigeria (1980-2016). International Journal of Research in Social Sciences, 8(7), 87-107.

Engle, R. F., \& Granger, C. W. (1987). Co-integration and error correction: representation, estimation, and testing. Econometrica: Journal of the Econometric Society, 55(2), 251-276. Available at: https://doi.org/10.2307/1913236.

Fan, T., Peters, M., \& Zilibotti, F. (2021). Service-led or service-biased growth? Equilibrium development accounting across Indian Districts. NBER Working Paper Series, Working Paper No. 28551.

Fei, J. C. H., \& Ranis, G. (1964). Development of a labor surplus economy: Theory and policy. Homewood, Illinois: Irwin.

Felipe, J., Mehta, A., \& Rhee, C. (2014). Manufacturing matters, but it's the jobs that count, Economics and Research Department Working Paper\# 420. Asian Development Bank, Metro Manila, 420, 1-35.

Ghani, E. (2011). The Service revolution. Paper presented at the Paper Presented at ILO Conference, Geneva, 2011.

Haraguchi, N., Cheng, C. F. C., \& Smeets, E. (2017). The importance of manufacturing in economic development: Has this changed? World Development, 93, 293-315. Available at: https://doi.org/10.1016/j.worlddev.2016.12.013.

Haug, A. A. (2002). Temporal aggregation and the power of cointegration tests: A Monte Carlo Study. Oxford Bulletin of Economics and Statistics, 64(4), 399-412. 
Hsieh, C.-T., \& Rossi-Hansberg, E. (2019). The industrial revolution in services. NBER Working Paper No. $25968 \mathrm{I}$.

Hwa, E. C. (1989). The contribution of agriculture to economic growth: Some empirical evidence. In J. Williamson \& V.R. Panchamurtchi

(Eds.), The Balance between industry and agriculture in economic development: Sector Proportions (Vol. 2). New York: The World Bank.

ILO. (2020). Tackling the youth employment challenge (pp. 1-92). Report on Employment in Africa (Re-Africa).

Johansen, S., \& Juselius, K. (1990). Maximum likelihood estimation and inference on cointegration—with appucations to the demand for money. Oxford Bulletin of Economics and Statistics, 52(2), 169-210. Available at: https://doi.org/10.1111/j.1468-0084.1990.mp52002003.x.

Kaldor, N. (1970). The case for regional policies. Scottish Journal of Political Economy, 17(3), 337-348.

Kuznets, S. (1971). Economic growth of nations: Cambridge, Massachusetts: Harvard University Press. London: Oxford University Press.

Laurenceson, J., \& Chai, C. H. (2003). Financial reform and economic development in China (pp. 1-28). Cheltenham, UK: Edward Elgar Publishing.

Lewis, W. A. (1954). Economic development with unlimited supplies of labour. Manchester School of Social Science, 22(2), $139-191$. Available at: https://doi.org/10.1111/j.1467-9957.1954.tbooo21.x.

Lodefalk, M. (2014). The role of services for manufacturing firm exports. Review of world Economics, 150(1), 59-82. Available at: https://doi.org/10.1007/s10290-013-0171-4.

Low, P. (2017). What we can learn from case studies on services. In B, Hoekman \& D. W te Velde (Eds.), Trade in services and economic transformation: A new development policy priority: Overseas Development Institute.

Miroudot, S. (2019). Services and manufacturing in global value chains: Is the distinction obsolete? (pp. 1-29). ADBI Working Paper Series No. 927.

National Skills Commission. (2020). 2020 employment projections - for the five years to November 2025. (A publication of the Australian Government, Department of Education, Skills and Employment) Retrieved from: https://lmip.gov.au/default.aspx?LMIP/EmploymentProjections.

Nayyar, G., \& Cruz, M. (2019). Developing countries and services in the new industrial paradigm. In M. Helble \& B. Shepherd (Eds). Leveraging services for development: Prospects and policies (pp. 17-42): Asian Development Bank Institute.

Ocampo, J. A. (2007). Industrial development for the 21st Century: Sustainable development perspectives. United Nations: Department of Economic and Social Affairs.

OECD. (2005). Growth in services fostering employment, productivity and innovation. OECD Digital Economy Papers, No. 94.

Olamade, O. (2017). Services sector growth and development sustainability in Nigeria. Journal of Business and Economic Development, 2(4), 204-2 14.

Pesaran, M., \& Shin, Y. (1999). An autoregressive distributed lag modeling approach to cointegration analysis. In S. Strom, (Ed) Econometrics and economic theory in the 20th Century: The ragnar frisch centennial symposium. Cambridge: Cambridge University Press.

Pesaran, M. H., Shin, Y., \& Smith, R. J. (2001). Bounds testing approaches to the analysis of level relationships. Journal of Applied Econometrics, $16(3)$, 289-326. Available at: https://doi.org/10.1002/jae.616.

Phillips, P. C., \& Hansen, B. E. (1990). Statistical inference in instrumental variables regression with I (1) processes. The Review of Economic Studies, 57(1), 99-125. Available at: https://doi.org/10.2307/2297545.

Shepherd, B. (2019). Productivity and trade growth in services: How services helped power factory Asia (pp. 1-18). ADBI Working Paper Series No. 914, Asian Development Bank Institute.

Stehrer, R., Baker, P., Foster-McGregor, N., Koenen, J., Leitner, S., Schricker, J., . . Yagafarova, A. (2015). Study on the relation between industry and services in terms of productivity and value creation WiiW Research Report 404, July 2015, 1138.

Syrquin, M. (1986). Productivity growth and factor reallocation. In: H, Chenery, S, Robinson, \& M, Syrquin (Eds.), Industrialization and growth - a comparative study (pp. 229-262). New York: Oxford University Press. 
Szirmai, A. (2009). Industrialization as an engine of growth in developing countries (pp. 1-50). UNU-MERIT Working Paper Series \#2009-010, United Nations University, Maastricht Economic and Social Research and Training Centre on Innovation and Technology.

Szirmai, A. (2011). Manufacturing and economic development (pp. 1-25). UNU-WIDER Working Paper No. 2011/75.

Szirmai, A., \& Verspagen, B. (2015). Manufacturing and economic growth in Developing Countries, 1950-2005. Structural Change and Economic Dynamics, 34, 46-59. Available at: https://doi.org/10.1016/j.strueco.2015.06.002.

Te Velde, D. W. (2017). Support economic transformation: Services and economic transformation. Paper presented at the UNCTAD Multi-year Expert Meeting on Trade, Services and Development, Geneva.

Timmer, M. P., \& Szirmai, A. (2000). Productivity growth in Asian manufacturing: the structural bonus hypothesis examined. Structural Change and Economic Dynamics, $11(4), 371-392$. Available at: https://doi.org/10.1016/s0954-349x(00)00023o.

UNCTAD. (2017). The role of the services economy and trade in structural transformation and inclusive development, TD/B/C.I/MEM.4/14.

Verspagen, B. (2000). Growth and structural change: Trends, patterns and policy options. Research Memorandum 015, Maastricht University, Maastricht Economic Research Institute on Innovation and Technology (MERIT).

WTO. (2019). The future of services trade (pp. 1-232). World Trade Report. 2019, WTO, Vienna.

Views and opinions expressed in this article are the views and opinions of the author(s), Asian Development Policy Review shall not be responsible or answerable for any loss, damage or liability etc. caused in relation to/arising out of the use of the content. 